\title{
ANALYSIS OF FACTORS AFFECTING FOOD DELIVERY USERS IN JABODETABEK
}

\author{
Marleene Ratu Fiorentina ${ }^{1}$ \\ ${ }^{1}$ Faculty of Economics, Universitas Negeri Jakarta \\ Jakarta, Indonesia \\ marlenratuu@gmail.com \\ Usep Suhud ${ }^{2}$ \\ ${ }^{2}$ Faculty of Economics, Universitas Negeri Jakarta \\ Jakarta, Indonesia \\ usuhud@unj.ac.id \\ Ika Febrilia ${ }^{3}$ \\ ${ }^{3}$ Faculty of Economics, Universitas Negeri Jakarta \\ Jakarta, Indonesia \\ ikafebrilia@unj.ac.id
}

\begin{abstract}
This study aims to test the positive and significant influence of Brand Image, Trust, and Perceived Value on Customer Loyalty and Repurchase Intention with Customer Satisfaction as an intervening variable on Food Delivery Users. The number of respondents to this study was 200 respondents who had used the food delivery application. The data analysis in this study used SPSS version 26 and SEM with AMOS program version 24 . The results of this study show that brand image has a positive and significant influence on customer satisfaction, perceived value has a positive and significant influence on customer satisfaction, trust has a positive and significant influence on customer satisfaction, customer satisfaction has a positive and significant influence on customer loyalty and customer satisfaction has a positive and significant influence on repurchase intentions. Implications for managerial: 1) Characteristics in a food delivery company need to be developed to have superior to competitors and increase the Brand Image. 2) It is necessary to increase the reliability of food delivery to create high trust. A reliable company can influence consumer trust. 3) It is necessary to improve the quality standard in food delivery to create a high perceived value. One of the service company's values, such as food delivery services, is service quality, so a
\end{abstract}


consistent quality standard is needed. 4) Customer expectations must be comparable and even exceed the services provided to increase customer satisfaction. 5) To increase customer loyalty, you must pay attention to customer satisfaction as the first choice when the need arises from consumers. 6) It is necessary to evaluate consumers who have used food delivery applications, to create high repurchase interest.

Keywords: Brand Image, Perceived Value, Trust, Customer Satisfaction, Customer Loyalty, Repurchase Intent, Food Delivery.

\section{INTRODUCTION}

In 2019 nearly 185 million people used the internet in Indonesia. This number is expected to grow to more than 256 million by 2025 (Number of Internet Users in Indonesia from 2015 to 2025, 2020). With more than 185 million internet users, Indonesia is one of the world's largest internet markets. As of July 2020, online penetration in Indonesia is more than $68 \%$. Mobile internet users are experiencing a growth rate and currently account for more than $61 \%$.

Food delivery service providers can be categorized as Restaurant-to-Consumer or Platform-to-Consumer Delivery Operations (Online Food Delivery, 2020). Restaurantto-Consumer Delivery Providers make food and deliver it, as indicated by providers, such as KFC, McDonald's, and Domino. Orders can be made directly through the restaurant's online platform or via a third-party platform. From 2019 to 2020, there was an increase of 5\% in Restaurant-to-Consumer Delivery and 4\% in Platform-to-Consumer Delivery. The world is currently in turmoil with the outbreak of the Covid-19 virus, which reportedly can spread rapidly from one person to another. This caused WHO to declare this virus a pandemic status, which applies to various regions with the rapid transmission. According to Shahrinaz et al. (2016), Brand Image is defined as information relating to brands in the memories of customers or, in other words, the associations and beliefs that consumers have in specific brands. Previous research conducted by (Pramesti \& Waluyo, 
2019) stated that Brand Image has a positive and significant effect on customer satisfaction but is inversely proportional to research (Tangguh et al., 2018), proving that brand image has no considerable impact on customer satisfaction. This statement can assume that brand image does not necessarily affect customer satisfaction with the products or services they have used previously.

Behind the increasing use of Food Delivery, it turns out that Food Delivery users experience problems. Like drivers that drain user balances, orders do not arrive even though the order status in the application has been completed (Ayu, 2019). According to Slater (1994) research, perceived value is usually considered a trade-off between two parties. One party obtains financial value and the other benefits from the consumption of a product or service.

Suyanto (2007) indicates that customer satisfaction compares performance and product expectations and feelings of pleasure or disappointment with customers. If the product's performance meets expectations, the customer is satisfied or happy. Conversely, if the product's account does not match expectations, customers will be disappointed. If the product performance exceeds expectations, the customer will feel delighted.

According to Gremler \& Brown (1996), customer loyalty refers to customers who repurchase goods or services and have a commitment and positive attitude towards service companies, such as recommending others to buy. Previous research conducted by Luarn \& Lin (2003) proved that there is a significant relationship between satisfaction and trust in loyalty, as well as commitment and loyalty. Meanwhile, Kandampully \& Hu (2007) confirms that building loyalty can be grown by service quality, satisfaction, and company image.

Repurchase Intention is one of the company's problems, as competition between service providers and product companies continues to grow worldwide. Previous research conducted by Huanget al. (2014) proves that customer satisfaction can signif icantly affect repurchase intentions This is assumed if satisfied consumers cannot reuse the products or service, they have used previously. Still, it is inversely proportional to the research results (Prastiwi, 2016), which shows that customer satisfaction has no significant impact on reuse intentions. 


\section{LITERATURE REVIEW}

\section{Brand Image}

According to Rangkuti (2011), Brand image is the perception of a brand associated with brand associations inherent in consumer memories. Companies with a good image try to attract their corporate identity by spreading their strengths or differences. According to Bauer et al. (2005), Brand Image is defined as the cumulative product of brand associations in the consumer's mind. This means that all brand associations in the customer's product or service mentality give rise to a product or service perception. In situations where differentiation of a product or service based on tangible quality features becomes difficult, Brand Image plays an important role (Jin et al., 2013).

The factors forming a brand image, according to (Keller, 2003) there are three, namely:

1. Favorability of brand association is a brand association where consumers believe that the attributes and benefits that arise from a brand can be sufficient or create a sense of satisfaction for consumers.

2. Strength of the brand association is a brand association as information recorded in the consumer's memory and survives as part of the Brand Image.

3. The uniqueness of brand association is must break down an association to brand into other brand categories.

\section{Trust}

Trust can be interpreted as perceptions that arise in the minds of consumers regarding the superiority of a product or service according to the experience gained by the consumer (Suhardi, 2006). "From the service provider side, trust is the emergence of a sense of security and fulfilment of the desires or expectations of consumers" (Zeithaml \& Bitner, 2006). Trust can be present if a person feels confident in the reliability and integrity of what he believes, then the value of trust appears (Hunt, 1994).

According to Mowen\&Minor (2002), trust is divided into three categories, namely:

1. Trust Object Attributes

2. Trust Benefit Attribute

3. Object Benefit Trust

According to Pavlou (2003) to measure the level of trust in e-commerce sites, namely:

1. Can be trusted 
2. Keeping promises and commitments

3. There is a thought to believe

\section{Perceived Value}

Perceived value occurs when someone believes that the product he wants is a product that is suitable and appropriate to buy. This view arises because of the opinions that arise in the community and the benefits felt by consumers when making a purchase. According to Oliver \& Desarbo (2014), "Perceived, Value comes from equity theory, which states that consumers consider the ratio of their results or inputs to service providers' yields or inputs. Revealed by Zeithaml (1988) define "Perceived Value is a sacrifice not only in the form of monetary costs but also includes non-monetary opportunity costs, which are commonly referred to as behavioural prices, such as the time and effort spent buying and using products and services. Perceived value is also believed to trigger customer satisfaction. When a customer gets a high service value, eating will result in high satisfaction.

Sweeneya (2001) perceived value is formed from four aspects, namely:

1. Emotional value: the use of positive emotional feelings or states generated by the product. When emotions produce a product or service, they will feel its emotional value.

2. Social value: use resulting from the product's ability to optimize social selfawareness. Social values are related to social acceptance and increased welfare between society and individuals.

3. Quality Value: use is obtained from evaluating the quality and the expected work results of the product. Performance results from a change in rate, and a shift in quality represents the physical work being done.

4. Price / Value for Money: the benefits of the product are felt due to reduced resources for both the short and long term.

\section{Customer Satisfaction}

Consumer satisfaction, according to Kotler (2009), "Is a feeling of pleasure or disappointment that arises after comparing the performance (results) of the product in mind against the expected performance (results)." According to Rangkuti (2011), the 
definition of customer satisfaction is the response of a customer when the previous level of importance does not match the actual perceived performance after use or use. Bitner (2008) expressed that customer satisfaction responds from customers and assesses the mismatch between expectations and actual service performance.

As expressed by Lupiyoadi (2001), there five factors to consider to customer satisfaction:

1. Product quality

2. Service quality

3. Emotional

4. Price

5. Cost and convenience

\section{Customer Loyalty}

According to Griffin (2005), It is disclosed that loyalty is a form of behaviour in determining decisions to make purchases from time to time on goods from the realm of the seller. Lovelock (2017) revealed that "loyalty is used in the realm of business to describe the willingness of buyers or consumers to use company products for a long time, especially if they are used exclusively and recommend these products to other relatives." Oliver (2010) expressed that loyalty is defined as a commitment from customers to return to buy consistently even though situational influences or marketing efforts make customers switch.

According to Gremler \& Brown (1996), There are three dimensions of Customer Loyalty, namely:

1. Behavioural Loyalty: Loyalty is caused by the results of the benefit evaluation by consumers. Behavioural loyalty refers to what consumers do.

2. Attitudinal Loyalty: Consumers choose to be loyal because of positive brand preferences (the brand meets the consumer's primary functional or emotional need). Attitude loyalty leads to what consumers feel.

3. Cognitive Loyalty: When consumers have awareness and expectations (when they need to decide what to buy or where to go, loyalty first comes to consumers' minds). 


\section{Repurchase Intention}

Suryana \& Dasuki (2013) defines Repurchase Intention as the tendency of buyers to behave from consumers to products or services repeated over a certain period and aware of past experiences. As expressed by John et al. (2003), "Repurchase Intention is taking into account the current situation, a separate evaluation of the purchase of a product or service from the same company." In the repurchase process, consumers continue to buy from the same company. Chiu et al. (2009) that Repurchase Intention It is possible that subjectively, someone will continue to buy products from suppliers or online stores later. According to Oly Ndubisi et al (2011), eight factors influence online Repurchase Intention.

1. Perceived Value

2. Perceived Ease of Use

3. Perceived Usefulness

4. Firm Reputation

5. Privacy

6. Trust

7. Reliability

8. Functionality

\section{Theoretical framework}

\section{Brand Image and Customer Satisfaction}

Budiatmo \& Aryaty (2016), To test Customer Satisfaction on Apple iPhone users at Diponegoro University, one of the hypotheses tested is research related to the relationship between Brand Image and Customer Satisfaction. As a result, there is a positive and significant influence on Customer Satisfaction on Apple iPhone users at Diponegoro University. This explanation was supported by research from Budiyanto (2018). To test Customer Satisfaction at PT Yerry Primatama Hosindo, one of the hypotheses tested in this study is Brand Image's effect on Customer Satisfaction. As a result, there is a positive influence on Customer Satisfaction at PT Yerry Primatama Hosindo. 


\section{Trust and Customer Satisfaction}

Muflihhadi \& Rubiyanti (2016), to testCustomer Satisfaction on Gojek users in Bandung, one of the hypotheses tested in their study is the influence of Trust on Customer Satisfaction. As a result, there is a positive influence on Customer Satisfaction with Gojek consumers in Bandung. This explanation aligns with Sonia \& Devi's (2018) to test Customer Satisfaction on Florist Online consumers in Denpasar City. One of the hypotheses tested in this study is the effect of Trust on Customer Satisfaction. As a result, there is a positive and significant influence on Customer Satisfaction on Florist Online consumers in Denpasar City.

\section{Perceived Value and Customer Satisfaction}

Hapsari etal. (2016), to test Customer Satisfaction on Indonesian airline users in Surabaya and Malang, one of the hypotheses tested in their research is the effect of Perceived Value on Customer Satisfaction. As a result, there is a positive influence on Customer Satisfaction among Indonesian airline users in Surabaya and Malang. This is also supported by research conducted by Tan (2019). To test Customer Satisfaction on Shopee consumers in Surabaya, one of the hypotheses tested in this study is perceived Value on Customer Satisfaction. As a result, there is a positive and significant influence on Customer Satisfaction among Shopee consumers in Surabaya.

\section{Customer Satisfaction and Customer Loyalty}

Ferdian (2012), to test Customer Loyalty in self-service consumers, Bangsri Jepara, one of the hypotheses tested in this study is the effect of Customer Satisfaction on Customer Loyalty. As a result, there is a positive and significant impact on Customer Loyalty on the blessing of self-service consumers in Bangsri Jepara. This explanation is supported by research from Kasiri et al. (2017). To test Customer Loyalty to consumers in three service sectors in Malaysia, one of the hypotheses tested in this study is Customer Satisfaction on Customer Loyalty. As a result, there is a positive and significant influence on Customer Loyalty among consumers in three service sectors in Malaysia.

\section{Customer Satisfaction and Repurchase Intention}

Tan (2019), to test Repurchase Intention on Shopee users in Surabaya, one of the hypotheses tested in this study is the effect of Customer Satisfaction on Repurchase Intention. As a result, there is a good and significant impact on Customer Loyalty among 
Shopee users in Surabaya. This explanation is in line with research by Lagitan \& Briliana (2018). To test Repurchase Intention on Lazada users, one of the hypotheses tested in this study is the effect of Customer Satisfaction on Repurchase Intention. As a result, there is a positive and significant effect on Repurchase Intention on Lazada users.

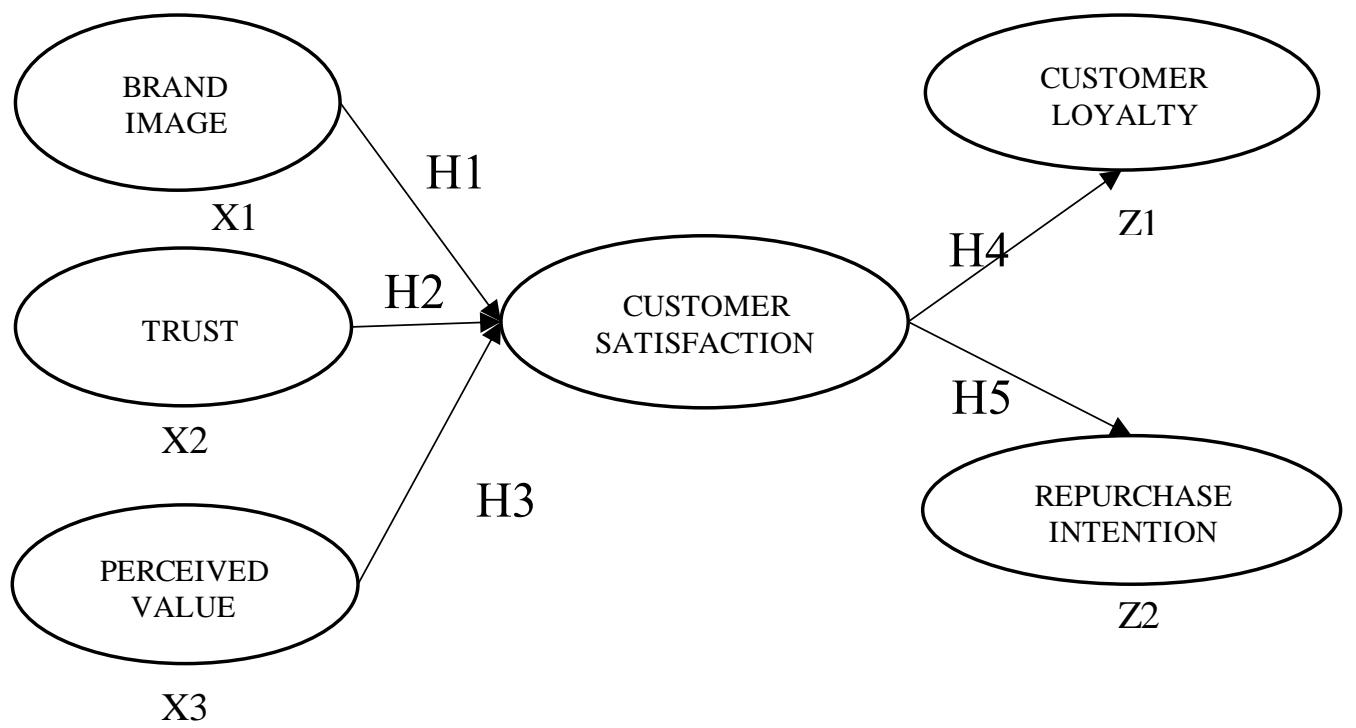

Figure 1. Research Model

Source: Data processed by researchers (2021)

\section{RESEARCH METHOD}

\section{Respondents}

Respondents in this study amounted to 200 people. From the data obtained, as many as 200 people, the majority of respondents were 123 women (61.5\%) and 77 men (38.5\%), with 77 people aged 21-25 years (38.5\%). ), and the majority of the work status is working as many as 135 people (67.5\%).

\section{Measurement}

In this study, the measurement scale used by researchers is the Likert scale. Research conducted by researchers uses an even scale or a six-point rating scale consisting of "strongly disagree" to "strongly agree."

There are five indicators for a brand image adapted from(Putu et al., 2018, p.15). There are five trust indicators adapted from (Flavián et al., 2005, p. 468); (Liang et al., 2018, p.46). There are five indicators of perceived value adapted from (Rivière \& Mencarelli, 
2012, p. 122). There are five indicators of customer satisfaction adapted from (Saad Andaleeb \& Conway, 2006, p. 10);(Huang, Chun-Chen., 2014, p.112). Five customer loyalty indicators have been adapted (Gremler \& Brown, 1996, p.173); (Ribbink et al., 2004 , p. 451). There are five indicators of repurchase intention, which were adapted from(Chiu et al., 2009, p. 784); (Wu et al., 2014, p. 5), (Lin \& Lekhawipat, 2014, p.611).

\section{RESULT AND DISCUSSION}

Descriptive Analysis

Table 1 Descriptive Analy sis Brand Image

\begin{tabular}{|l|c|c|c|c|c|c|}
\hline \multicolumn{1}{|c|}{ Statement } & STS & TS & SDT & SDS & S & SS \\
\hline \multirow{2}{*}{$\begin{array}{l}\text { Food Delivery the ones I use } \\
\text { often are well known }\end{array}$} & 1 & 7 & 5 & 36 & 85 & 66 \\
\cline { 2 - 7 } & $0.5 \%$ & $3.5 \%$ & $2.5 \%$ & $18.0 \%$ & $42.5 \%$ & $33.0 \%$ \\
\hline \multirow{2}{*}{$\begin{array}{l}\text { Food Delivery the ones I use } \\
\text { often are easy to remember }\end{array}$} & 0 & 7 & 12 & 25 & 95 & 61 \\
\cline { 2 - 8 } & $0.0 \%$ & $3.5 \%$ & $6.0 \%$ & $12.5 \%$ & $47.5 \%$ & $30.5 \%$ \\
\hline $\begin{array}{l}\text { Food Delivery the ones I use } \\
\text { often have their characteristics }\end{array}$ & 1 & 5 & 18 & 46 & 89 & 41 \\
\cline { 2 - 8 } $\begin{array}{l}\text { Food Delivery the ones I use } \\
\text { often are easy to use }\end{array}$ & 2 & 8 & 11 & 27 & 70 & 82 \\
\hline \multirow{2}{*}{$\begin{array}{l}\text { Food Delivery the ones I use } \\
\text { often are the best brands }\end{array}$} & $1.0 \%$ & $4.0 \%$ & $5.5 \%$ & $13.5 \%$ & $35.0 \%$ & $41.0 \%$ \\
\hline Percentage & $0.5 \%$ & $3.5 \%$ & $7.0 \%$ & $12.0 \%$ & $51.0 \%$ & $26.0 \%$ \\
\hline
\end{tabular}

Source: Data processed by researchers (2021)

Of the five indicators, the Brand Image (BI) option Agree (S) has a total percentage of $44.1 \%$, with the statement " Food Delivery the ones I use often are the best brands " was chosen the most, namely by $51 \%$ or 102 respondents. It can be concluded that respondents tend to respond positively to statements on the Brand Image variable. 
Table 2. Descriptive Analysis Trust

\begin{tabular}{|l|c|c|c|c|c|c|}
\hline \multicolumn{1}{|c|}{ Statement } & STS & TS & SDT & SDS & S & SS \\
\hline $\begin{array}{l}\text { I trust Food Delivery which I often } \\
\text { use to make my cash transactions }\end{array}$ & 1 & 5 & 9 & 26 & 108 & 51 \\
\cline { 2 - 7 } & $0.5 \%$ & $2.5 \%$ & $4.5 \%$ & $13.0 \%$ & $54.0 \%$ & $25.5 \%$ \\
\hline $\begin{array}{l}\text { I trust Food Delivery which I often } \\
\text { use to make my transactions via } \\
\text { the internet }\end{array}$ & 2 & 2 & 8 & 41 & 109 & 38 \\
\cline { 2 - 8 } & $1.0 \%$ & $1.0 \%$ & $4.0 \%$ & $20.5 \%$ & $54.5 \%$ & $19.0 \%$ \\
\hline $\begin{array}{l}\text { Food Delivery which I often use, } \\
\text { can keep its promises and } \\
\text { commitments }\end{array}$ & 1 & 6 & 6 & 35 & 100 & 52 \\
\cline { 2 - 8 } & $0.5 \%$ & $3.0 \%$ & $3.0 \%$ & $17.5 \%$ & $50.0 \%$ & $26.0 \%$ \\
\hline $\begin{array}{l}\text { I think the Food Delivery that I use } \\
\text { often will keep the promise it } \\
\text { made me. }\end{array}$ & 1 & 4 & 15 & 51 & 73 & 56 \\
\cline { 2 - 8 } & $0.5 \%$ & $2.0 \%$ & $7.5 \%$ & $25.5 \%$ & $36.5 \%$ & $28.0 \%$ \\
\hline $\begin{array}{l}\text { I believe the Food Delivery that I } \\
\text { often use is reliable }\end{array}$ & 2 & 5 & 21 & 37 & 97 & 38 \\
\hline Percentage & $1.0 \%$ & $2.5 \%$ & $10.5 \%$ & $18.5 \%$ & $48.5 \%$ & $19.0 \%$ \\
\hline
\end{tabular}

Source: Data processed by researchers (2021)

Of the five indicators Trust (TR), the Agree (S) option has a total percentage of $48.7 \%$ with the statement "I trust Food Delivery, which I often use to do my transactions via the internet" was chosen the most, namely by $54.5 \%$ or 109 respondents. It can be concluded that respondents tend to respond positively to statements on the Trust variable.

Table 3. Descriptive Analysis Perceived Value

\begin{tabular}{|l|c|c|c|c|c|c|}
\hline \multicolumn{1}{|c|}{ Statement } & STS & TS & SDT & SDS & S & SS \\
\hline $\begin{array}{l}\text { Food Delivery what I often use, } \\
\text { is one of the services I enjoy }\end{array}$ & 2 & 7 & 10 & 41 & 92 & 48 \\
\cline { 2 - 8 } & $1.0 \%$ & $3.5 \%$ & $5.0 \%$ & $20.5 \%$ & $46.0 \%$ & $24.0 \%$ \\
\hline $\begin{array}{l}\text { Food Delivery the ones I use } \\
\text { often make a good impression }\end{array}$ & 0 & 8 & 15 & 36 & 99 & 42 \\
\cline { 2 - 8 } & $0.0 \%$ & $4.0 \%$ & $7.5 \%$ & $18.0 \%$ & $49.5 \%$ & $21.0 \%$ \\
\hline
\end{tabular}




\begin{tabular}{|c|c|c|c|c|c|c|}
\hline Statement & STS & TS & SDT & SDS & $\mathbf{S}$ & SS \\
\hline \multirow{2}{*}{$\begin{array}{l}\text { Food Delivery which I often use, } \\
\text { is an economical service product }\end{array}$} & 1 & 6 & 26 & 52 & 83 & 32 \\
\hline & $0.5 \%$ & $3.0 \%$ & $13.0 \%$ & $26.0 \%$ & $41.5 \%$ & $16.0 \%$ \\
\hline \multirow{2}{*}{$\begin{array}{l}\text { Food Delivery the ones I use } \\
\text { of ten have good quality } \\
\text { standards }\end{array}$} & 4 & 7 & 22 & 23 & 103 & 41 \\
\hline & $2.0 \%$ & $3.5 \%$ & $11.0 \%$ & $11.5 \%$ & $51.5 \%$ & $20.5 \%$ \\
\hline \multirow{2}{*}{$\begin{array}{l}\text { Food Delivery the ones I use } \\
\text { of ten have consistent quality }\end{array}$} & 0 & 6 & 28 & 37 & 91 & 38 \\
\hline & $0.0 \%$ & $3.0 \%$ & $14.0 \%$ & $18.5 \%$ & $45.5 \%$ & $19.0 \%$ \\
\hline Percentage & $0.7 \%$ & $3,4 \%$ & $10.1 \%$ & $18.9 \%$ & $46.8 \%$ & $20.1 \%$ \\
\hline
\end{tabular}

Source: Data processed by researchers (2021)

Of the five indicators of Perceived Value (PV), the Agree (S) option has a total percentage of $46.8 \%$, with the statement "Food Delivery which I often use has good quality standards" was chosen the most, namely by $51.5 \%$ or 103 respondents. It can be concluded that respondents tend to respond positively to statements on the Perceived Value variable.

Table 4. Descriptive Analy sis Customer Satisfaction

\begin{tabular}{|c|c|c|c|c|c|c|}
\hline Statement & STS & TS & SDT & SDS & $\bar{S}$ & SS \\
\hline \multirow{2}{*}{$\begin{array}{l}\text { The experience of using Food } \\
\text { Delivery, which I often use, is } \\
\text { fun }\end{array}$} & 1 & 7 & 22 & 26 & 87 & 57 \\
\hline & $0.5 \%$ & $3.5 \%$ & $11.0 \%$ & $13.0 \%$ & $43.5 \%$ & $28.5 \%$ \\
\hline \multirow{2}{*}{$\begin{array}{l}\text { The decision to choose food } \\
\text { delivery that I often use is the } \\
\text { right choice }\end{array}$} & 1 & 5 & 27 & 19 & 81 & 67 \\
\hline & $0.5 \%$ & $2.5 \%$ & $13.5 \%$ & $9.5 \%$ & $40.5 \%$ & $33.5 \%$ \\
\hline \multirow{2}{*}{$\begin{array}{l}\text { Food delivery, which I often } \\
\text { use, the quality of service is } \\
\text { excellent. }\end{array}$} & 1 & 9 & 28 & 38 & 85 & 39 \\
\hline & $0.5 \%$ & $4.5 \%$ & $14.0 \%$ & $19.0 \%$ & $42.5 \%$ & $19.5 \%$ \\
\hline \multirow{2}{*}{$\begin{array}{l}\text { I think the Food Delivery that } \\
\text { I often use is up to my } \\
\text { expectations }\end{array}$} & 0 & 13 & 29 & 29 & 87 & 42 \\
\hline & $0.0 \%$ & $6.5 \%$ & $14.5 \%$ & $14.5 \%$ & $43.5 \%$ & $21.0 \%$ \\
\hline
\end{tabular}




\begin{tabular}{|l|c|c|c|c|c|c|}
\hline Statement & STS & TS & SDT & SDS & S & SS \\
\hline $\begin{array}{l}\text { Overall, I am satisfied with the } \\
\text { Food Delivery that I use } \\
\text { frequently }\end{array}$ & 1 & 7 & 8 & 38 & 101 & 45 \\
\cline { 2 - 7 } & $0.5 \%$ & $3.5 \%$ & $4.0 \%$ & $19.0 \%$ & $50.5 \%$ & $22.5 \%$ \\
\hline Percentage & $0.4 \%$ & $4.1 \%$ & $11.4 \%$ & $15.0 \%$ & $44.1 \%$ & $25.0 \%$ \\
\hline
\end{tabular}

Source: Data processed by researchers (2021)

Of the five indicators of Customer Satisfaction (CS), the Agree (S) option has a total percentage of $44.1 \%$ with the statement " Overall, I am satisfied with the Food Delivery that I use frequently" was chosen the most, namely by $50.5 \%$ or 101 respondents. It can be concluded that respondents tend to respond positively to statements on the Customer Satisfaction variable.

Table 5. Descriptive Analysis Customer Loyalty

\begin{tabular}{|l|c|c|c|c|c|c|}
\hline \multicolumn{1}{|c|}{ Statement } & STS & TS & SDT & SDS & S & SS \\
\hline $\begin{array}{l}\text { I say positive things about Food } \\
\text { Delivery that I often use to other } \\
\text { people }\end{array}$ & 0 & 11 & 11 & 27 & 89 & 62 \\
\cline { 2 - 7 } & $0.0 \%$ & $5.5 \%$ & $5.5 \%$ & $13.5 \%$ & $44.5 \%$ & $31.0 \%$ \\
\hline $\begin{array}{l}\text { I recommend the Food Delivery } \\
\text { which I often use to someone } \\
\text { asking for my advice }\end{array}$ & 1 & 4 & 6 & 31 & 102 & 56 \\
\cline { 2 - 7 } & $0.5 \%$ & $2.0 \%$ & $3.0 \%$ & $15.5 \%$ & $51.0 \%$ & $28.0 \%$ \\
\hline $\begin{array}{l}\text { I will encourage friends and } \\
\text { relatives to use the food delivery } \\
\text { that I often use }\end{array}$ & 2 & 4 & 7 & 24 & 102 & 61 \\
\hline \multirow{2}{*}{$\begin{array}{l}\text { Food Delivery which I often use, is } \\
\text { the first choice when I want to } \\
\text { order food. }\end{array}$} & 1 & $2.0 \%$ & $3.5 \%$ & $12.0 \%$ & $51.0 \%$ & $30.5 \%$ \\
\cline { 2 - 7 } & $0.5 \%$ & $1.0 \%$ & $3.0 \%$ & $11.5 \%$ & $60.5 \%$ & $23.5 \%$ \\
\hline $\begin{array}{l}\text { I prefer the Food Delivery service } \\
\text { which I often use compared to } \\
\text { others }\end{array}$ & 2 & 11 & 15 & 34 & 77 & 61 \\
\cline { 2 - 7 } & $1.0 \%$ & $5.5 \%$ & $7.5 \%$ & $17.0 \%$ & $38.5 \%$ & $30.5 \%$ \\
\hline Percentage & $0.6 \%$ & $3,2 \%$ & $4.5 \%$ & $13.9 \%$ & $49.1 \%$ & $28.7 \%$ \\
\hline
\end{tabular}




\section{Source: Data processed by researchers (2021)}

Of the five indicators of Customer Loyalty (CL), the Agree (S) option has a total percentage of $49.1 \%$ with the statement "Food Delivery which I often use is the first choice when I want to order food" was chosen the most, namely by $60.5 \%$ or 121 respondents. It can be concluded that respondents tend to respond positive ly to statements on the Customer Loyalty variable.

Table 6. Descriptive Analysis Repurchase Intention

\begin{tabular}{|l|c|c|c|c|c|c|}
\hline \multicolumn{1}{|c|}{ Statement } & STS & TS & SDT & SDS & S & SS \\
\hline I intend to continue buying & 2 & 8 & 11 & 25 & 91 & 63 \\
\cline { 2 - 7 } $\begin{array}{l}\text { products from Food Delivery that I } \\
\text { frequently use in the future }\end{array}$ & $1.0 \%$ & $4.0 \%$ & $5.5 \%$ & $12.5 \%$ & $45.5 \%$ & $31.5 \%$ \\
\hline $\begin{array}{l}\text { Chances are I will use this Food } \\
\text { Delivery which I often use again }\end{array}$ & 3 & 3 & 4 & 32 & 102 & 56 \\
\cline { 2 - 8 } $\begin{array}{l}\text { If I had to do it again, I would go } \\
\text { for the Food Delivery, which I use } \\
\text { frequently }\end{array}$ & 3 & 3 & 7 & 22 & 103 & 62 \\
\cline { 2 - 8 } & $1.5 \%$ & $1.5 \%$ & $3.5 \%$ & $11.0 \%$ & $51.5 \%$ & $31.0 \%$ \\
\hline $\begin{array}{l}\text { It looks like I'll be buying back } \\
\text { from the Food Delivery which I } \\
\text { frequently u se, soon }\end{array}$ & 3 & 1 & 7 & 21 & 120 & 48 \\
\cline { 2 - 8 } & $1.5 \%$ & $0.5 \%$ & $3.5 \%$ & $10.5 \%$ & $60.0 \%$ & $24.0 \%$ \\
\hline $\begin{array}{l}\text { I am anticipating buying back from } \\
\text { the Food Delivery that I use } \\
\text { frequently }\end{array}$ & 2 & 8 & 15 & 32 & 83 & 60 \\
\cline { 2 - 8 } & $1.0 \%$ & $4.0 \%$ & $7.5 \%$ & $16.0 \%$ & $41.5 \%$ & $30.0 \%$ \\
\hline Percentage & $1.3 \%$ & $2.3 \%$ & $4.4 \%$ & $13.2 \%$ & $49.9 \%$ & $28.9 \%$ \\
\hline
\end{tabular}

Source: Data processed by researchers (2021)

Of the five indicators, the Repurchase Intention (RI) option Agree (S) has a total percentage of $49.9 \%$ with the statement "It looks like I'll be buying back from the Food Delivery which I frequently use, soon" was chosen by $60 \%$ or 120 respondents. It can be concluded that respondents tend to respond positively to statements on the Repurchase Intention variable. 


\section{Validity Test}

\section{Exploratory Factor Analysis (EFA)}

The EFA instrument test results are declared valid if they have a factor loadings value> 0.4 (Hair et al. 1998). The following are the results of the validity of this test.

Table 7. Exploratory Factor Analysis (Brand Image)

\begin{tabular}{|l|l|l|}
\hline \multicolumn{1}{|c|}{ Item } & \multicolumn{1}{|c|}{ Statement } & \multicolumn{1}{|c|}{ Factor Loadings } \\
\hline BI 1 & $\begin{array}{l}\text { Food Delivery the ones I use often are well } \\
\text { known. }\end{array}$ & 0.728 \\
\hline BI 2 & $\begin{array}{l}\text { Food Delivery the ones I use often are easy to } \\
\text { remember. }\end{array}$ & 0.713 \\
\hline BI 3 & $\begin{array}{l}\text { Food Delivery the ones I use often have their } \\
\text { characteristics }\end{array}$ & 0.646 \\
\hline BI 4 & $\begin{array}{l}\text { Food Delivery the ones I use often are easy to } \\
\text { use. }\end{array}$ & 0.789 \\
\hline BI 5 & $\begin{array}{l}\text { Food Delivery the ones I use often are the best } \\
\text { brands. }\end{array}$ & 0.695 \\
\hline
\end{tabular}

Source: Data processed by researchers (2021)

This is because the loadings factor value of all indicators of the Brand Image variable is above 0.4 . It can be concluded that all indicators are declared valid.

Table 8. Exploratory Factor Analysis (Trust)

\begin{tabular}{|l|l|l|}
\hline \multicolumn{1}{|c|}{ Item } & \multicolumn{1}{|c|}{ Statement } & \multicolumn{1}{|c|}{ Factor Loadings } \\
\hline TR 1 & $\begin{array}{l}\text { I trust Food Delivery which I often use to } \\
\text { make my cash transactions. }\end{array}$ & 0.717 \\
\hline TR 2 & $\begin{array}{l}\text { Food Delivery the ones I use often are easy } \\
\text { to remember. }\end{array}$ & 0.696 \\
\hline TR 3 & $\begin{array}{l}\text { I trust Food Delivery which I often use to } \\
\text { make my transactions via the internet. }\end{array}$ & 0.514 \\
\hline
\end{tabular}




\begin{tabular}{|l|l|l|}
\hline Item & Statement & Factor Loadings \\
\hline TR 4 & $\begin{array}{l}\text { Food Delivery the ones I use often are easy } \\
\text { to use }\end{array}$ & 0.509 \\
\hline TR 5 & $\begin{array}{l}\text { Food Delivery which I often use can keep } \\
\text { its promises and commitments. }\end{array}$ & 0.600 \\
\hline
\end{tabular}

Source: Data processed by researchers (2021)

This is because the loadings factor value of all indicators of the Trust variable is above 0.4. So can be concluded that all indicators are declared valid.

Table 9. Exploratory Factor Analysis (Perceived Value)

\begin{tabular}{|l|l|l|}
\hline \multicolumn{1}{|c|}{ Item } & \multicolumn{1}{|c|}{ Statement } & \multicolumn{1}{|c|}{ Factor Loadings } \\
\hline PV 1 & $\begin{array}{l}\text { Food Delivery what I often use is one of } \\
\text { the services I enjoy. }\end{array}$ & 0.858 \\
\hline PV 2 & $\begin{array}{l}\text { Food Delivery the ones I use often make a } \\
\text { good impression. }\end{array}$ & 0.813 \\
\hline PV 3 & $\begin{array}{l}\text { Food Delivery which I often use is an } \\
\text { economical service product. }\end{array}$ & 0.809 \\
\hline PV 4 & $\begin{array}{l}\text { Food Delivery the ones I use often have } \\
\text { good quality standards. }\end{array}$ & 0.808 \\
\hline PV 5 & $\begin{array}{l}\text { Food Delivery the ones I use often have } \\
\text { consistent quality. }\end{array}$ & 0.791 \\
\hline
\end{tabular}

Source: Data processed by researchers (2021)

This is because the loadings factor value of all indicators of the Perceived Value variable is above 0.4 . It can be concluded that all indicators are declared valid. 
Table 10. Exploratory Factor Analysis (Customer Satisfaction)

\begin{tabular}{|l|l|l|}
\hline \multicolumn{1}{|c|}{ Item } & \multicolumn{1}{|c|}{ Statement } & \multicolumn{1}{|c|}{ Factor Loadings } \\
\hline CS 1 & $\begin{array}{l}\text { The experience of using Food Delivery, } \\
\text { which I often use, is fun. }\end{array}$ & 0.869 \\
\hline CS 2 & $\begin{array}{l}\text { The decision to choose food delivery that I } \\
\text { often use is the right choice. }\end{array}$ & 0.847 \\
\hline CS 3 & $\begin{array}{l}\text { Food delivery, which I often use, the } \\
\text { quality of service is excellent }\end{array}$ & 0.821 \\
\hline CS 4 & $\begin{array}{l}\text { I think the Food Delivery that I often use is } \\
\text { up to my expectations. }\end{array}$ & 0.813 \\
\hline CS 5 & $\begin{array}{l}\text { Overall, I am satisfied with the Food } \\
\text { Delivery that I use frequently. }\end{array}$ & 0.794 \\
\hline
\end{tabular}

Source: Data processed by researchers (2021)

This is because the loadings factor value of all indicators of the Customer Satisfaction variable is above 0.4 . It can be concluded that all indicators are declared valid.

Table 11. Exploratory Factor Analysis (Customer Loyalty)

\begin{tabular}{|l|l|l|}
\hline Item & Statement & Factor Loadings \\
\hline CL 1 & $\begin{array}{l}\text { I say positive things about Food Delivery } \\
\text { that I often use to other people. }\end{array}$ & 0.879 \\
\hline CL 2 & $\begin{array}{l}\text { I recommend Food Delivery, which I often } \\
\text { use to someone asking for my advice. }\end{array}$ & 0.846 \\
\hline CL 3 & $\begin{array}{l}\text { I will encourage friends and relatives to } \\
\text { use the food delivery that I often use. }\end{array}$ & 0.783 \\
\hline CL 4 & $\begin{array}{l}\text { FoodDelivery which Ioften use, is the first } \\
\text { choice when I want to order food. }\end{array}$ & 0.778 \\
\hline CL 5 & $\begin{array}{l}\text { I prefer the Food Delivery service which I } \\
\text { often use compared to others. }\end{array}$ & 0.763 \\
\hline
\end{tabular}

Source: Data processed by researchers (2021) 
This is because the loadings factor value of all indicators of the Customer Loyalty variable is above 0.4. It can be concluded that all indicators are declared valid.

Table 12. Exploratory Factor Analysis (Repurchase Intention)

\begin{tabular}{|l|l|l|}
\hline Item & Statement & Factor Loadings \\
\hline RI 1 & $\begin{array}{l}\text { I intend to continue buying products from } \\
\text { Food Delivery that I frequently use in the } \\
\text { future. }\end{array}$ & 0.879 \\
\hline RI 2 & $\begin{array}{l}\text { Chances are I will use this Food Delivery } \\
\text { which I often use again. }\end{array}$ & 0.854 \\
\hline RI 3 & $\begin{array}{l}\text { If I had to do it again, I would go for the } \\
\text { Food Delivery, which I use frequently. }\end{array}$ & 0.829 \\
\hline RI 4 & $\begin{array}{l}\text { It looks like I'll be buying back from the } \\
\text { Food Delivery, which I frequently use, } \\
\text { soon. }\end{array}$ & 0.807 \\
\hline RI 5 & $\begin{array}{l}\text { I am anticipating buying back from the } \\
\text { Food Delivery that I use frequently. }\end{array}$ & 0.784 \\
\hline
\end{tabular}

Source: Data processed by researchers (2021)

This is because the loadings factor value of all indicators of the Repurchase Intention variable is above 0.4 . So can be concluded that all indicators are declared valid.

\section{Confirmatory Factor Analysis (CFA)}

\section{Brand Image Variable}

Table 13. Preliminary Results of the CFA Test (Brand Image)

\begin{tabular}{|c|c|c|c|}
\hline $\begin{array}{c}\text { The goodness of Fit } \\
\text { Index }\end{array}$ & Cut-off Value & Result & $\begin{array}{c}\text { Model } \\
\text { Evaluation }\end{array}$ \\
\hline X2, Chi-Square & Smaller is better & 1,423 & Corresponding \\
\hline Probability & $\geq 0.05$ & 0.223 & Corresponding \\
\hline GFI & $\geq 0.90$ & 0.989 & Corresponding \\
\hline RMSEA & $\leq 0.08$ & 0.046 & Corresponding \\
\hline
\end{tabular}




\begin{tabular}{|c|c|c|c|}
\hline $\begin{array}{c}\text { The goodness of Fit } \\
\text { Index }\end{array}$ & Cut-off Value & Result & $\begin{array}{c}\text { Model } \\
\text { Evaluation }\end{array}$ \\
\hline AGFI & $\geq 0.90$ & 0.958 & Corresponding \\
\hline TLI & $\geq 0.90$ & 0.993 & Corresponding \\
\hline NFI & $\geq 0.90$ & 0.990 & Corresponding \\
\hline
\end{tabular}

Source: Data processed by researchers (2021)

After testing, the model has no indicators that need to be removed because it has met the conformity requirements. So it can be stated that the model on the Brand Image variable is appropriate/fit.

\section{Trust variable}

Table 14. Preliminary Results of the CFA Test (Trust)

\begin{tabular}{|c|c|c|c|}
\hline $\begin{array}{c}\text { The goodness of Fit } \\
\text { Index }\end{array}$ & Cut-off Value & Result & $\begin{array}{c}\text { Model } \\
\text { Evaluation }\end{array}$ \\
\hline X2, Chi-Square & Smaller is better & 0.269 & Corresponding \\
\hline Probability & $\geq 0.05$ & 0.930 & Corresponding \\
\hline GFI & $\geq 0.90$ & 0.997 & Corresponding \\
\hline RMSEA & $\leq 0.08$ & 0,000 & Corresponding \\
\hline AGFI & $\geq 0.90$ & 0.992 & Corresponding \\
\hline TLI & $\geq 0.90$ & 1,020 & Corresponding \\
\hline NFI & $\geq 0.90$ & 0.996 & Corresponding \\
\hline
\end{tabular}

Source: Data processed by researchers (2021)

After testing, the model has no indicators that need to be removed because it has met the conformity requirements. So it can be stated that the model on the Trust variable is appropriate/fit. 
Variable Perceived Value Variable

Table 15. Initial CFA Test Results (Perceived Value)

\begin{tabular}{|c|c|c|c|}
\hline $\begin{array}{c}\text { The goodness of Fit } \\
\text { Index }\end{array}$ & Cut-off Value & Result & $\begin{array}{c}\text { Model } \\
\text { Evaluation }\end{array}$ \\
\hline X2, Chi-Square & Smaller is better & 0.932 & Corresponding \\
\hline Probability & $\geq 0.05$ & 0.459 & Corresponding \\
\hline GFI & $\geq 0.90$ & 0.991 & Corresponding \\
\hline RMSEA & $\leq 0.08$ & 0,000 & Corresponding \\
\hline AGFI & $\geq 0.90$ & 0.972 & Corresponding \\
\hline TLI & $\geq 0.90$ & 1,001 & Corresponding \\
\hline NFI & $\geq 0.90$ & 0.990 & Corresponding \\
\hline
\end{tabular}

Source: Data processed by researchers (2021)

After testing, the model has no indicators that need to be removed because it meets the conformity requirements. So can be stated that the model on the Perceived Value variable is appropriate/fit.

\section{Customer Satisfaction Variable}

Table 16. Initial CFA Test Results (Customer Satisfaction)

\begin{tabular}{|c|c|c|c|}
\hline $\begin{array}{c}\text { The goodness of Fit } \\
\text { Index }\end{array}$ & Cut-off Value & Result & $\begin{array}{c}\text { Model } \\
\text { Evaluation }\end{array}$ \\
\hline X2, Chi-Square & Smaller is better & 1,427 & Corresponding \\
\hline Probability & $\geq 0.05$ & 0.211 & Corresponding \\
\hline GFI & $\geq 0.90$ & 0.987 & Corresponding \\
\hline RMSEA & $\leq 0.08$ & 0.046 & Corresponding \\
\hline AGFI & $\geq 0.90$ & 0.961 & Corresponding \\
\hline TLI & $\geq 0.90$ & 0.992 & Corresponding \\
\hline NFI & $\geq 0.90$ & 0.986 & Corresponding \\
\hline
\end{tabular}

Source: Data processed by researchers (2021) 
Based on the Customer Satisfaction variable instrument test, there are five measurable indicators with the code "CS01-CS05". After testing, the model has no indicators that need to be removed because it meets the conformity requirements. So can state that the model on the Customer Satisfaction variable is appropriate/fit.

\section{Customer Loyalty Variable}

Table 17. InitialCFA Test Results (Customer Loyalty)

\begin{tabular}{|c|c|c|c|}
\hline $\begin{array}{c}\text { The goodness of Fit } \\
\text { Index }\end{array}$ & Cut-off Value & Result & $\begin{array}{c}\text { Model } \\
\text { Evaluation }\end{array}$ \\
\hline X2, Chi-Square & Smaller is better & 1,323 & Corresponding \\
\hline Probability & $\geq 0.05$ & 0.251 & Corresponding \\
\hline GFI & $\geq 0.90$ & 0.987 & Corresponding \\
\hline RMSEA & $\leq 0.08$ & 0.040 & Corresponding \\
\hline AGFI & $\geq 0.90$ & 0.960 & Corresponding \\
\hline TLI & $\geq 0.90$ & 0.993 & Corresponding \\
\hline NFI & $\geq 0.90$ & 0.986 & Corresponding \\
\hline
\end{tabular}

Source: Data processed by researchers (2021)

Based on the Customer Loyalty variable instrument test, there are five measurable indicators with the code "CL01-CL05". After testing, the model has no indicators that need to be removed because it meets the conformity requirements. So can state that the model on the Customer Loyalty variable is appropriate/fit.

\section{Repurchase Intention Variable}

Table 18. Initial CFA Test Results (Repurchase Intention)

\begin{tabular}{|c|c|c|c|}
\hline $\begin{array}{c}\text { The goodness of Fit } \\
\text { Index }\end{array}$ & Cut-off Value & Result & $\begin{array}{c}\text { Model } \\
\text { Evaluation }\end{array}$ \\
\hline X2, Chi-Square & Smaller is better & 0.907 & Corresponding \\
\hline Probability & $\geq 0.05$ & 0.475 & Corresponding \\
\hline GFI & $\geq 0.90$ & 0.991 & Corresponding \\
\hline RMSEA & $\leq 0.08$ & 0,000 & Corresponding \\
\hline
\end{tabular}




\begin{tabular}{|c|c|c|c|}
\hline $\begin{array}{c}\text { The goodness of Fit } \\
\text { Index }\end{array}$ & Cut-off Value & Result & $\begin{array}{c}\text { Model } \\
\text { Evaluation }\end{array}$ \\
\hline AGFI & $\geq 0.90$ & 0.974 & Corresponding \\
\hline TLI & $\geq 0.90$ & 1,002 & Corresponding \\
\hline NFI & $\geq 0.90$ & 0.991 & Corresponding \\
\hline
\end{tabular}

Source: Data processed by researchers (2021)

Based on the instrument test for the Repurchase Intention variable, there are five measurable indicators with the code "RI01-RI05". After testing, the model has no indicators that need to be removed because it meets the conformity requirements. So can state that the model on the Repurchase Intention variable is appropriate/fit.

\section{Reliability Test}

Table 19. Reliability Test Results

\begin{tabular}{|c|c|c|}
\hline Variable & Cronbach's Alpha & Evaluation \\
\hline Brand Image $(X 1)$ & 0,900 & Reliable \\
\hline Trust $(X 2)$ & 0,833 & Reliable \\
\hline Perceived Value $(X 3)$ & 0,874 & Reliable \\
\hline Customer Satisfaction $(Y)$ & 0,884 & Reliable \\
\hline Customer Loyalty $(Z 1)$ & 0,863 & Reliable \\
\hline Repurchase Intention $(Z 2)$ & 0,885 & Reliable \\
\hline
\end{tabular}

Source: Data processed by researchers (2021)

It can state that all variables are reliable because they exceed Cronbach's Alpha $\geq 0.60$ and can be used for further testing. 


\section{SEM Model}

Full Model SEM

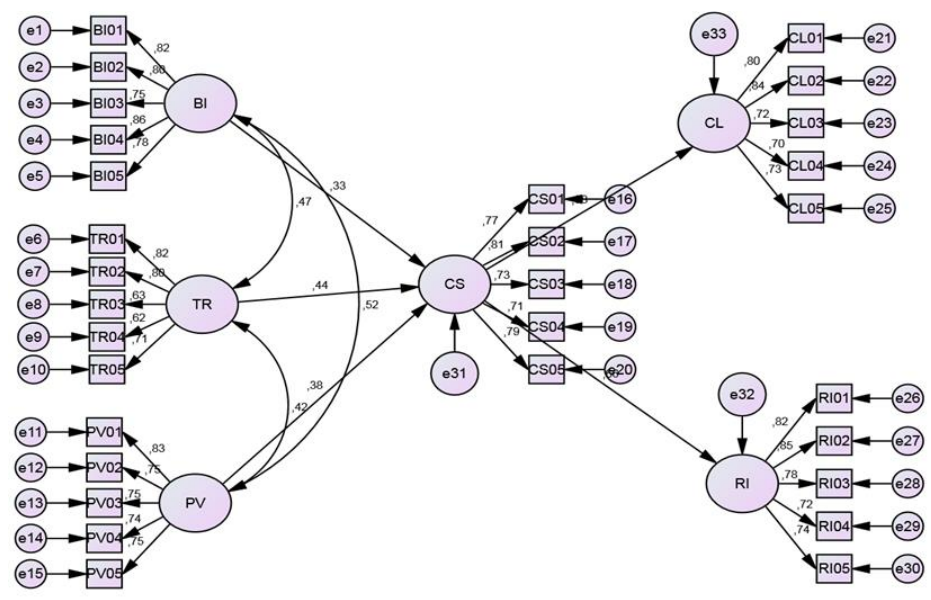

Figure 2. Full SEM Model

Source: Data processed by researchers (2021)

Table 20. Test Results Full Model SEM

\begin{tabular}{|c|c|c|c|}
\hline $\begin{array}{c}\text { The goodness of Fit } \\
\text { Index }\end{array}$ & Cut-off Value & Result & $\begin{array}{c}\text { Model } \\
\text { Evaluation }\end{array}$ \\
\hline X2, Chi-Square & Smaller is better & 1,197 & Corresponding \\
\hline Probability & $\geq 0.05$ & 0.004 & $\begin{array}{c}\text { It is not } \\
\text { following }\end{array}$ \\
\hline GFI & $\geq 0.90$ & 0.861 & $\begin{array}{c}\text { It is not } \\
\text { following }\end{array}$ \\
\hline RMSEA & $\geq 0.08$ & 0.031 & Corresponding \\
\hline AGFI & $\geq 0.90$ & 0.837 & $\begin{array}{c}\text { It is not } \\
\text { following }\end{array}$ \\
\hline TLI & $\geq 0.90$ & 0.976 & Corresponding \\
\hline NFI & $\geq 0.90$ & 0.882 & $\begin{array}{c}\text { It is not } \\
\text { following }\end{array}$ \\
\hline
\end{tabular}

Source: Data processed by researchers (2021) 
If the model does not reach the expected value, adjustments need to be made so that researchers can obtain a model that meets the appropriate standards and can carry out further testing.

Fit Model SEM

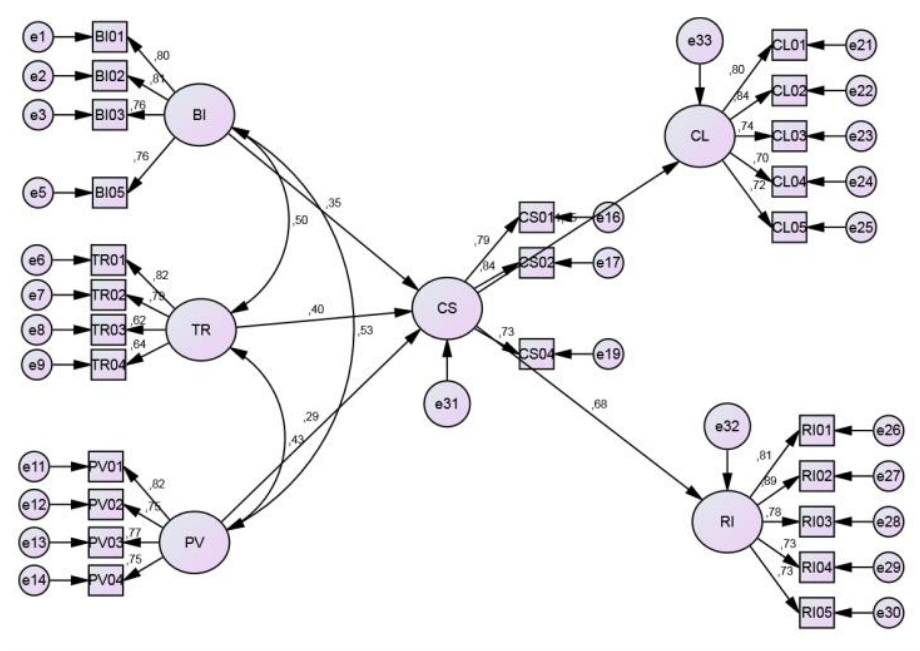

Figure 3. Fit Model SEM

Source: Data processed by researchers (2021)

Table 21. Test Results Fit Model

\begin{tabular}{|l|l|l|l|}
\hline $\begin{array}{l}\text { The goodness of Fit } \\
\text { Index }\end{array}$ & Cut-off Value & Result & $\begin{array}{l}\text { Model } \\
\text { Evaluation }\end{array}$ \\
\hline X2, Chi-Square & Smaller is better & 0.832 & Corresponding \\
\hline Probability & $\geq 0.05$ & 0.978 & Corresponding \\
\hline GFI & $\geq 0.90$ & 0.992 & Corresponding \\
\hline RMSEA & $\leq 0.08$ & 0,000 & Corresponding \\
\hline AGFI & $\geq 0.90$ & 0.903 & Corresponding \\
\hline TLI & $\geq 0.90$ & 1,018 & Corresponding \\
\hline NFI & $\geq 0.90$ & 0.929 & Corresponding \\
\hline
\end{tabular}

Source: Data processed by researchers (2021)

Based on the SEM model fit test results, several indicators need to be removed so that the tested model meets the suitability requirements. In the SEM full model test, the Brand Image variable has five indicators. The results of the adjusted fit model show the value of X2, Chi-Square $=0.832 ;$ Probability $=0.978 ;$ GFI $=0.992 ;$ RMSEA $=0,000 ;$ AGFI $=$ 
0.903; TLI $=1,018 ; \mathrm{NFI}=0.929 ; \mathrm{PNFI}=0.814$. From these results it $\mathrm{can}$ be said that the research model is appropriate/fit.

Table 22. Estimation Results Model

\begin{tabular}{|c|c|c|c|c|c|c|c|c|}
\hline Hypothesis & $\begin{array}{l}\text { Dependen } \\
\text { t variable }\end{array}$ & & $\begin{array}{l}\text { Independent } \\
\text { Variable }\end{array}$ & Estimate & SE & CR & $\mathbf{P}$ & Result \\
\hline $\mathrm{H} 1$ & $\begin{array}{l}\text { Customer } \\
\text { Satisfactio } \\
n\end{array}$ & $\leftarrow$ & Brand Image & 0.380 & $\begin{array}{l}0.6 \\
0\end{array}$ & $\begin{array}{l}6,31 \\
9\end{array}$ & $\begin{array}{l}* * \\
*\end{array}$ & $\begin{array}{l}\mathrm{Be} \\
\text { accepte } \\
\text { d }\end{array}$ \\
\hline $\mathrm{H} 2$ & $\begin{array}{l}\text { Customer } \\
\text { Satisfactio } \\
n\end{array}$ & $\leftarrow$ & Trust & 0.458 & $\begin{array}{l}, \\
06 \\
4\end{array}$ & $\begin{array}{l}7,16 \\
7\end{array}$ & $\begin{array}{l}* * \\
*\end{array}$ & $\begin{array}{l}\mathrm{Be} \\
\text { accepte } \\
\mathrm{d}\end{array}$ \\
\hline $\mathrm{H} 3$ & $\begin{array}{l}\text { Customer } \\
\text { Satisfactio } \\
n\end{array}$ & 4 & $\begin{array}{l}\text { Perceived } \\
\text { Value }\end{array}$ & 0.296 & $\begin{array}{l}0.0 \\
52\end{array}$ & $\begin{array}{l}5,73 \\
1\end{array}$ & $\begin{array}{l}* * \\
*\end{array}$ & $\begin{array}{l}\mathrm{Be} \\
\text { accepte } \\
\mathrm{d}\end{array}$ \\
\hline $\mathrm{H} 4$ & $\begin{array}{l}\text { Customer } \\
\text { Loyalty }\end{array}$ & $\leftarrow$ & $\begin{array}{l}\text { Customer } \\
\text { Satisfaction }\end{array}$ & 1,130 & $\begin{array}{l}0.1 \\
02\end{array}$ & $\begin{array}{l}11,0 \\
45\end{array}$ & $\begin{array}{l}* * \\
*\end{array}$ & $\begin{array}{l}\mathrm{Be} \\
\text { accepte } \\
\mathrm{d}\end{array}$ \\
\hline $\mathrm{H} 5$ & $\begin{array}{l}\text { Repurchas } \\
\text { e Intention }\end{array}$ & $\leftarrow$ & $\begin{array}{l}\text { Repurchase } \\
\text { Intention }\end{array}$ & 0.682 & $\begin{array}{l}0.0 \\
81\end{array}$ & $\begin{array}{l}8,45 \\
1\end{array}$ & $\begin{array}{l}* * \\
*\end{array}$ & $\begin{array}{l}\mathrm{Be} \\
\text { accepte } \\
\mathrm{d}\end{array}$ \\
\hline
\end{tabular}

Source: Data processed by researchers (2021)

\section{Discussion}

H1: Brand Image on Customer Satisfaction has a positive and significant effect. This shows that the better the perception in consumers' minds towards a company's brand image, the higher the Customer Satisfaction will be. On the other hand, if consumers have imperfect perceptions of a company's Brand Image, Customer Satisfaction will also be lower. These results are consistent with Budiatmo (2016), Budiyanto (2018), and Budiastari (2018) who also examined Brand Image's influence on Customer Satisfaction. 
H2: Trust in Customer Satisfaction has a positive and significant effect. This shows that the higher the consumer's sense of trust in a company, the higher the Customer Satisfaction will be. Conversely, if the consumer's sense of confidence is getting lower in a company, the Customer Satisfaction will also be lower. These results follow the research conducted by Muflihhadi \& Rubiyanti (2016) and Sonia \& Devi (2018), who also examined the effect of Trust on Customer Satisfaction.

H3: Perceived Value on Customer Satisfaction has a positive and significant effect. This shows that the higher the consumer has Perceived Value, the sense that a product/service shows that high quality can arouse consumers' emotional side. Customer Satisfaction will also be higher. Conversely, if the consumer's Perceived Value gets lower on the quality of a product/service, the Customer Satisfaction will also be lower. These results follow the research conductedHapsari et al. (2016) and Tan (2019), who also examined the effect of perceived value on customer satisfaction.

H4: Customer Satisfaction variable on Customer Loyalty has a positive and significant effect. This shows that the higher the Customer Satisfaction level with a company, the higher the Customer Loyalty will be. Conversely, if Customer Satisfaction is lower for a company, Customer Loyalty will also be lower. These results follow the research conducted Ferdian (2012), Kasiri et al. (2017), and Hermawan et al (2020) who also examined Customer Satisfaction's effect on Customer Loyalty.

H5: Customer Satisfaction variable on Repurchase Intention has a positive and significant effect. This shows that increasing the Customer Satisfaction with a company, the higher the level of Repurchase Intention. Conversely, if Customer Satisfaction is lower for a company, the Repurchase Intention level will also be lower. This result follows the research conducted by Tan (2019) and Lagita \& Briliana (2018), who also examined the effect of Customer Satisfaction on Repurchase Intention. 


\section{CONCLUSION}

1. The first hypothesis states that the Brand Image variable (X1) positively and significantly affects Customer Satisfaction (Y).

2. The second hypothesis states that the Trust variable (X2) positively and significantly affects Customer Satisfaction (Y).

3. The third hypothesis states that the variable Perceived Value (X2) positively and significantly affects Customer Satisfaction (Y).

4. The fourth hypothesis states that the Customer Satisfaction (Y) variable positively and significantly affects Customer Loyalty (Z1).

5. The fifth hypothesis states that the Customer Satisfaction (Y) variable positively and significantly affects Repurchase Intention (Z2).

Implications for management:

1. Characteristics in a food delivery company need to be developed to have superior to competitors and increase the Brand Image.

2. It is necessary to increase the reliability of food delivery to create high trust. A reliable company can influence consumer trust.

3. It is necessary to improve the quality standard in food delivery to create a high perceived value. One of the service company's values, such as food delivery services, is service quality, so a consistent quality standard is needed.

4. Customer expectations must be comparable and even exceed the services provided so that customer satisfaction can increase.

5. To increase customer loyalty, y ou must pay attention to customer satisfaction as the first choice when the need arises from consumers.

6. It is necessary to evaluate consumers who have used food delivery applications, to create high repurchase interest.

Implications for academics:

1. Academically, this research seeks to increase brand image, trust, perceived value, customer satisfaction, customer loyalty, and repurchase intention.

2. As consideration for conducting further research related to the food delivery business. 
3. This research can be a reference and consideration for academics in choosing food delivery.

4. Can help the problems of everyday life at least through research get the answers that are being faced.

\section{References}

Ayu, L. A. (2019). Pengemudi Sedot Saldo OVO dan Rugikan Konsumen, Grab Persilakan Lapor. Kompas. https://money.kompas.com/read/2019/07/31/124151126/pengemudi-sedot-saldoovo-dan-rugikan-konsumen-grab-persilakan-lapor?page=all

Bauer, H. H., Sauer, N. E., \& Exler, S. (2005). The loyalty of German soccer fans: does a team's brand image matter? International Journal of Sports Marketing and Sponsorship, 7(1), 8-16. https://doi.org/10.1108/ijsms-07-01-2005-b004

Budiyanto, A. (2018). Pengaruh Persepsi Harga, Kualitas Layan an dan Brand Image Terhadap Tingkat Kepuasan Konsumen di PT. Yerry Primatama Hosindo. Jurnal Pemasaran Kompetitif, 1(3), 71-80.

Chiu, C. M., Chang, C. C., Cheng, H. L., \& Fang, Y. H. (2009). Determinants of customer repurchase intention in online shopping. Online Information Review, 33(4), 761-784. https://doi.org/10.1108/14684520910985710

F., R. (2011). Riset Pemasaran. Gramedia Pustaka Utama.

Gremler, D. D., \& Brown, S. W. (1996). Service loyalty: Its Nature, Importance, and Implications. Advancing Service Quality: A Global Perspective, June, 171-180.

Griffin, J. (2005). Customer Loyalty: Menumbuhkan dan Mempertahankan Kesetiaan Pelanggan (Alih Bahas). Erlangga.

Hair, Joseph F, et al. (1998). Multivariate data Analysis. Prentice Hall.

Huang, Chun-Chen., S.-W. Y. and C.-Y. L. (2014). The Relationship Among Brand Equity, Customer Satisfaction, And Brand Resonance To Repurchase Intention of Cultural and Creative Industries In Taiwan. The International Journal of Organizational Innovation, 6(3), 106-121. http://ijoionline.org/attachments/article/38/FINAL_ISSUE_VOL_6_NUM_3_JANUARY_2 014.pdf\#page $=106$ 
Hunt, R. M. M. and S. D. (1994). The Commitment-Trust Theory of Relationship Marketing. Journal of Economic Theory, 58(3), 20-38. https://doi.org/10.1016/0022-0531(82)90041-2

Jillian C. Sweeneya, G. N. S. (2001). Consumer perceived value: The development of a multiple item scale. Journal of Retailing, 77, 203-220.

Jin, N. P., Lee, S., Huffman, L., \& Huffman, L. (2013). Impact of Restaurant Experience on Brand Image and Customer Loyalty : Moderating Role of Dining Motivation . 3741. https://doi.org/10.1080/10548408.2012.701552

John C Mowen; Michael Minor. (2002). Perilaku Konsumen (Kedua). Erlangga.

Kandampully, J., \& hu, H. H. (2007). Do hoteliers need to manage image to retain loyal customers? International Journal of Contemporary Hospitality Management, 19(6), 435-443. https://doi.org/10.1108/09596110710775101

Kevin Lane Keller. (2003). Strategic Brand Management, Building, Measuring, and Managing Brand Equity. Prentice Hall.

Kotler, Philip;Kevin, L. K. (2009). Manajemen Pemasaran (13th ed.). Salemba Empat.

L.G, D. A., \& Budiatmo, A. (2016). Pelanggan Melalui Kepuasan Pelanggan ( Pengguna Apple Iphone Di Jurusan Manajemen Universitas Diponegoro Semarang ). 5, 1-9. https://ejournal3.undip.ac.id/index.php/djom/article/view/14186

Lovelock Christopher. (2017). Pemasaran Jasa (7th ed.). Erlangga.

Luarn, P., \& Lin, H. H. (2003). A Customer Loyalty Model for E-Service Context. Journal of Electronic Commerce Research, 4(June), 156-167.

Muflihhadi, I., \& Rubiyanti, R. N. (2016). Pengaruh Perceived Usefulness, Perceived Ease of Use , Dan Trust Terhadap Kepuasan Konsumen ( Studi Pada Gojek Bandung ) the Impact of Perceived Usefulness, Perceived Ease of Use, and Trust in Custome Rs, Satisfaction ( Case Study in Gojek Bandung ). E-Proceeding of Management, 3(2), 2026-2033.

Number of internet users in Indonesia from 2015 to 2025. (2020). Statista Research Department. https://www.statista.com/statistics/254456/number-of-internet-usersin-indonesia/

Oliver, R. L., \& Desarbo, W. S. (2014). Response Satisfaction Determinants in Judgments. 
Journal of Consumer Research, 14(4), 495-507.

Oly Ndubisi, N., Har Lee, C., Cyril Eze, U., \& Oly Ndubisi, N. (2011). Analyzing key determinants of online repurchase intentions. Asia Pacific Journal of Marketing and Logistics, 23(2), 200-221. https://doi.org/10.1108/13555851111120498

Online Food Delivery. (2020). Statista. https://www.statista.com/outlook/374/117/online-food-delivery/china

Pavlou, P. A. (2003). Consumer acceptance of electronic commerce: Integrating trust and risk with the technology acceptance model. International Journal of Electronic Commerce, 7(3), 101-134. https://doi.org/10.1080/10864415.2003.11044275

Pramesti, A. B., \& Waluyo, H. D. (2019). Pengaruh Brand Image Dan Customer Value Terhadap Repurchase Intention Melalui Customer Satisfaction. Pengaruh Brand Image Dan Customer Value Terhadap Repurchase Intention Melalui Customer Satisfaction, 8(1), 8-13.

Prastiwi, S. K. (2016). Menguji Faktor-faktor yang Berpengaruh terhadap Repurchase Intention pada Produk Mie Instan Indomie di Indonesia. Jurnal EKA CIDA, 1(1), 96-109. https://doi.org/2503-3689

Rambat Lupiyoadi, A. H. (2001). Manajemen Pemasaran Jasa. Salemba Empat.

Shahrinaz, I., Yacob, Y., Hummida, D., \& Abdul, A. (2016). Relationship and impact of e-WOM and brand image towards purchase intention of smartphone? Journal of Scientific Research and Development, 3(5), 117-124.

Slater SF, N. J. (1994). Market orientation, customer value, and superior performance. Business Horizons.

Suhardi. (2006). Faktor-faktor yang Mempengaruhi Kepercayaan dan Loyalitas Nasabah Perbankan di Surabaya. Jurnal Kinerja .

Suryana, P., \& Dasuki, E. S. (2013). Analisis Faktor yang Mempengaruhi Keputusan Pembelian dan Implikasinya pada Minat Beli Ulang. Trikonomika, 12(2), 190. https://doi.org/10.23969/trikonomika.v12i2.479

Suyanto. (2007). Marketing Strategy Top Brand Indonesia. Andi.

Tangguh, G. G., Pangestuti, E., \& Nuralam, I. P. (2018). Pengaruh Citra Merek, Kualitas Layanan, dan Harga Terhadap Kepuasaan Pelanggan Go-Ride. Jurnal Administrasi Bsinis, 61(2), 118-126. 
Zeithaml, Bitner, G. (2006). Service Marketing (Fourth Edi). Prentice Hall.

Zeithaml, V. A. (1988). Consumer Perceptions of Price, Qualitye. Journal of Marketing, $52(3), 2-22$. 